\title{
PENERAPAN KEBIJAKAN DISKRESI DALAM KAITANNYA DENGAN TINDAK PIDANA KORUPSI
}

Oleh :

\author{
Ervien Rizky Aditya ${ }^{1}$
}

\begin{abstract}
Government in carrying out its duties is equipped with the authority of both the attributive and the delegative. With the development of society, there are often certain urgent circumstances, in which Government Officials/Administration Bodies can not use their authority which is bound to take legal action. In realizing the goal as a state with the concept of welfare general (welfare state) then the government must play an active role in interfacing the field of social economic life of the community. The government delegated responsibility bestuurszorg or public service. With this discretionary authority it means that some of the powers held by the legislature are transferred into the administration of the state as the executive body. Because the state administration has solved the problem by not waiting for the amendment of the Law from the legislative field, so the government should not refuse to provide services to the public on the grounds that there is no or no clear rule of law as long as it is still the authority of the government. But the power of government as a discretionary policy maker is always faced with a problem connected with corruption.
\end{abstract}

Keywords: State Administration, Discretion, Corruption.

\begin{abstract}
Abstrak
Pemerintah dalam menjalankan tugasnya dilengkapi dengan kewenangankewenangan baik yang bersifat atributif maupun yang bersifat delegatif. Dengan adanya perkembangan masyarakat maka seringkali terdapat keadaankeadaan tertentu yang sifatnya mendesak, dimana Pejabat/Badan Administrasi pemerintahan tidak dapat menggunakan kewenangannya yang bersifat terikat dalam melakukan tindakan hukum. Dalam mewujudkan tujuan sebagai negara dengan konsep kesejahteraan umum maka pemerintah harus berperan aktif mencampuri bidang kehidupan sosial ekonomi masyarakat. Maka pemerintah dilimpahkan tanggung jawab sebagai pelayan publik atau public service. Dengan adanya kewenangan diskresi ini berarti bahwa sebagian kekuasaan yang dipegang oleh badan pembentuk Undang-Undang dipindahkan ke dalam administrasi negara sebagai badan eksekutif. Karena administrasi negara melakukan penyelesaian masalah dengan tidak menunggu perubahan Undang-Undang dari bidang legislatif, sehingga pemerintah tidak boleh menolak memberikan pelayanan kepada masyarakat dengan alasan tidak ada atau tidak jelasnya aturan hukum sepanjang masih menjadi kewenangan dari pemerintah. Namun kekuasaan pemerintah sebagai pembuat kebijakan diskresi selalu berhadapan dengan adanya suatu permasalahan yang dihubungkan dengan tindak pidana korupsi.
\end{abstract}

Kata kunci: Administrasi Negara, Diskresi, Korupsi.

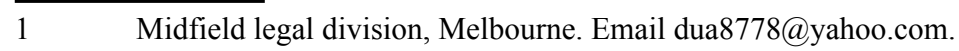




\section{PENDAHULUAN}

Kekuasaan merupakan sumber kewenangan dan konflik merupakan konsekuensi yang ditimbulkan dari pelaksanaan kewenangan yang tidak jelas, sehingga kekuasaan, kewenangan dan konflik merupakan hal yang sukar untuk dipisahkan satu sama lain terlebih bila berbicara mengenai kehidupan bernegara. Konflik merupakan konsekuensi dari tuntutan struktur birokratis terhadap adanya otoritas kewenangan untuk menjalankan fungsi-fungsi pemerintahan dalam jumlah yang banyak dan tidak menutup kemungkinan menimbulkan overlapping sehingga ketidakjelasan antara lembaga pemerintah yang berasal dari atribusi yang digariskan melalui pembagian kekuasaan negara oleh konstitusi, delegasi, dan mandat adalah kewenangan yang berasal dari pelimpahan.

Konflik antar penyelenggara administrasi negara yang tidak dapat diselesaikan melalui sinkronisasi di tingkat instansi atasan maka penyelesaian secara hukum harus ditempuh melalui lembaga peradilan.

Birokrasi sebenarnya merupakan instrumen kekuasaan yang didesain oleh pemerintah untuk menjalankan keputusan-keputusan politiknya dalam arti formil, namun dalam praktiknya birokrasi telah menjadi kekuatan politik yang berpotensial merobohkan kekuasaan. Oleh karena itu sistem dan prosedur penyelenggaraan negara dalam rangka pelaksanaan tugas pemerintahannegaradanpembangunan harus diatur oleh produk hukum².

Diskresi merupakan keputusan dan/atau tindakan yang ditetapkan dan/atau dilakukan oleh pejabat pemerintahan untuk mengatasi persoalan konkret yang dihadapi dalam penyelenggaraan pemerintahan dalam hal peraturan PerundangUndangan yang memberikan pilihan, tidak mengatur, tidak lengkap atau tidak jelas, dan/atau adanya stagnasi pemerintahan. Namun, penggunaannya harus oleh pejabat yang berwenang dan sesuai dengan tujuannya. ${ }^{3}$

Asas-asas umum pemerintahan yang baik dalam prakteknya secara yuridis mengikat penyelenggara negara untuk dilaksanakan dalam tugas dan fungsinya. Setiap badan atau pejabat pemerintahan dalam menjalankan tanggung jawabnya wajib melaksanakan asas-asas umum pemerintahan yang baik yang bertujuan adanya penyalahgunaan wewenang dan larangan bertindak sewenangwenang.

Badan atau pejabat pemerintah yang menggunakan diskresi wajib mempertanggungjawabkan keputusannya kepadapejabatatasannya dan masyarakat yang dirugikan akibat keputusan diskresi yang telah diambil.

2 Freies Ermessen, http://malut-post.com/berita/ index.php?option $=$ com_content\&task $=$ view \& $\mathrm{id}=163 \&$ Itemid $=38$, diakses pada 1 November 2017.

3 Diskresi,http://www.hukumon-line.com/ klinik/detail/1t54b538f5f35f5/arti--tujuan-lingkup--dan--contoh--diskresi, diakses pada 23 November 2017. 
Pertanggungjawaban kepada atasan dilaksanakan dalam bentuk tertulis dengan memberikan alasan-alasan pengambilan keputusan diskresi.

Secara umum istilah korupsi mengacu kepada berbagai tindakan gelap dan tidak sah (illicit or illegal activities) untuk mendapatkan keuntungan pribadi atau kelompok. Tetapi dalam perkembangannya pengertian korupsi terdapat penekanan bahwa korupsi adalah penyalahgunaan kekuasaan atau kedudukan publik untuk keuntungan pribadi. Dalam kerangka ini maka korupsi adalah lembaga ekstra legal yang digunakan individu atau kelompok untuk mendapat pengaruh terhadap kebijakan dan tindakan birokrasi ${ }^{4}$.

Salah satu contoh kasus mengenai Diskresi adalah Menyangkut kasus korupsi yang melibatkan Kepala Daerah di Indonesia, terdapat sebanyak 30 (tiga puluh) kasus korupsi yang ditangani oleh KPK sejak tahun 2004-2010. Dilihat dari substansi nya, terdapat setidaknya 4 (empat) lokus korupsi pada semua kasus tersebut, yaitu: (1) pengadaan barang dan jasa yang melanggar ketentuan atau aturan, (2) penyalahgunaan APBD untuk keperluan pribadi dan diluar jabatan, (3) pemberian atau penerbitan izin yang tidak sesuai dengan kewenangan atau prosedur serta (4) pemberian atau penerimaan suap ${ }^{5}$. Rendahnya tingkat 4 Munawar Fuad Noeh, 2005, Kiai Di Republik Maling, Republika, Jakarta, hlm.1

5 Teguh Kurniawan, Desertasi, Isu Diskresi Dalam Kasus Korupsi Kepala Daerah Yang Ditangani Oleh Komisi Pemeberantasan Ko- penyerapan anggaran oleh Pemerintah Daerah disebabkan oleh sejumlah hal, salah satunya yang dianggap penting adalah sebagai akibat dari kendala hukum yang dihadapi oleh para Kepala Daerah sehingga menyebabkan ketakutan dalam penggunaan anggaran daerah. Ketakutan dari para Kepala Daerah akan kriminalisasi tentu saja sangat beralasan dengan melihat sejumlah permasalahan hukum yang dihadapi oleh sejumlah Kepala Daerah di Indonesia, misalnya sebagaimana dinyatakan oleh pihak Kementerian Dalam Negeri dalam Diskusi Pencegahan Korupsi yang diadakan oleh Dewan Pimpinan Pusat (DPP) Partai Demokrat pada 12 Juli 2012, bahwa sejak 2004 hingga 2012 terdapat 213 (dua ratus tiga belas) Kepala Daerah yang tersangkut perkara korupsi baik sebagai saksi, tersangka, terdakwa, maupun terpidana (Kompas, 2012). Hal lainnya yang sangat memprihatinkan adalah kenyataan bahwa sejumlah mantan Kepala Daerah yang dianggap inovator

rupsi Pada Periode 2004-2010 dab Telah Memiliki Kekuatan Hukum Tetap, Universitas Indonesia, Jakarta, available at: https://www. researchgate.net/profile/Teguh_Kurniawan/ publication/317845377_Isu_Direksi_dalam Kasus_Korupsi_Kepala_Daerah_yang_Ditangani_oleh Komisi Pemberantasan Korupsi_pada Periode_2004 2010 dan Telah Memiliki_Kekuatan_Hukum_Tetap_or in English_Issues on Discretion in Cor/ links/594e $31 \mathrm{e} 945851543382 \mathrm{e} 9 \mathrm{bfd} / \mathrm{Isu}-\mathrm{Dis}-$ kresi-dalam-Kasus-Korupsi-Kepala-Daerahyang-Ditangani-oleh-Komisi-PemberantasanKorupsi-pada-Periode-2004-2010-dan-TelahMemiliki-Kekuatan-Hukum-Tetap-or-in-English-Issues-on-Discretion-in-Cor.pdf. diakses pada 1 November 2017. 
dan berhasil membangun daerahnya pun pada akhirnya tersandung kasus korupsi dan telah dinyatakan bersalah oleh Pengadilan, seperti yang dialami oleh I Gede Winasa (Mantan Bupati Jembrana) dan Untung Wiyono (Mantan Bupati Sragen) ${ }^{6}$.

Berbagai kasus korupsi tersebut, di asumsikan memiliki sejumlah keterkaitan dengan diskresi. Pelanggaran berbagai ketentuan dalam pengadaan barang dan jasa maupun penyalahgunaan APBD serta pemberian atau penerbitan izin dalam berbagaikasustersebutmenurutpeneliti memiliki kemungkinan keterkaitan dengan diskresi. Keterkaitan ini sangat dimungkinkan karena berbagai kasus tersebut melibatkan penggunaan kewenangan dari para Kepala Daerah. Sementara itu, untuk kasus penyuapan, terdapat kasus suap yang dilakukan untuk mempengaruhi proses pembuatan kebijakan oleh Kepala Daerah sehingga sangat mungkin juga terkait dengan diskresi, karena melibatkan pula penggunaan kewenangan dari Kepala Daerah yang terlibat.

Mengacu uraian pada latar belakang masalah tersebut, maka dapat di identifikasikan pokok permasalahan yang akan diteliti lebih lanjut pertama Apakah yang menjadi dasar pemikiran hukum adanya diskresi dalam rangka

\footnotetext{
6 Anonim, http://bali.bisnis.com/read/20140324 /9/43889/ma-vonmantan-bupati-jembranawinasa-, http://m.tempo.co/read/news/2012 /11/08/063440456/Mantan-Bupati-SragenSegera-Dijebloskan-ke-Penjara, diakses pada 26 November 2017.
}

mewujudkan Pemerintahan yang baik (good governance) ?, kedua Apakah implikasi hukum penggunaan diskresi dalam kaitannya dengan tindak pidana korupsi ?

Orisinalitas dalam penelitian ini yang terdapat dari penelitianpenelitian sebelumnya sebagai berikut: pertama dari jurnal magister hukum udayana yang berjudul kewenangan pemerintah dalam pembentukan peraturan kebijakan yang ditulis oleh Ni Luh Gede Astariyani, lebih pada menguraikan hukum tata pengaturan dalam negara hukum kesejahteraan (welfare state) ${ }^{7}$.

Kedua dari jurnal magister hukumudayana berjudul legalstanding komisi pemberantasan tindak pidana korupsi dalam sengketa kewenangan lembaganegara dimahkamahkonstitusi yang ditulis oleh I Gusti Ayu Eviani Yuliantari, lebih menggambarkan kejelasanmengenaistatuskelembagaan komisi pemberantasan tindak pidana korupsi dalam sistem ketatanegaraan Indonesia ${ }^{8}$.

7 Ni Luh Gede Astariyani, Kewenangan Pemerintah Dalam Pembentukan Peraturan Kebijakan,. Jurnal Magister Hukum Udayana (Udayana Master Law Journal), vol.4 no.4 tahun 2015.https://ojs.unud.ac.id/index.php/ jmhu/article/view/18746/12225, diakses pada 23 November 2017.

8 I Gustu Ayu Wviani Yuliantari, Legal Standing Komisi Pemberantasan Tindak Pidana Korupsi Dalam Sengketa Kewenangan Lembaga Negara Di Mahkamah Konstitusi, Jurnal Magister Hukum Udayana (Udayana Master Law Journal), vol.4 no.2 tahun 2015,https://ojs.unud.ac.id/index.php/jmhu/ article/view/17525/11475, diakses pada 23 November 2017. 
Ketiga jurnal magister hukum udayana berjudul pengawasan terhadap penyalahgunaan wewenang polisi republik Indonesia mengadakan tindakan lain menurut hukum yang bertanggung jawab (diskresi) yang ditulis oleh Made Suteja, memaparkan mengenai makna diskresi dalam menunjang tugas dan wewenang kepolisian republik Indonesia ${ }^{9}$.

Dari ketiga jurnal tersebut belum satupun yang menunjukkan secara umum penerapan dan akibat suatu kebijakan diskresi oleh pejabat negara dikaitkan dengan tindak pidana korupsi.

Tujuan dari penelitian ini adalah untuk mengetahui sejauh mana pelaksanaan diskresi tidak dikategorikan sebagai suatu tindakan yang salah dan berkaitan dengan tindak pidana korupsi sehingga suatu kebijakan yang diambil oleh pejabat negara dilaksanakan dengan tidak menimbulkan masalah hukum di kemudian hari yang berdampak adanya kerugian di masyarakat.

\section{METODE PENELITIAN}

Penelitian ini dirancang sebagai penelitian hukum dengan metode yuridis normatif yaitu metode yang objek penelitiannya berasal dari

9 Made Suteja, Pengawasan Terhadap Penyalahgunaan Wewenang Polri Mengadakan Tindakan Lain Menurut Hukum Yang Bertanggungjawab (Diskresi), Jurnal Magister Hukum Udayana (Udayana Master Law journal), vol.2 no.2 tahun 2015, https://ojs.unud.ac.id/index.php/jmhu/article/ view/7283/5526, diakses pada 23 November 2017. norma, kaidah, asas, dan prinsipprinsip yang terkandung dalam suatu peraturan Perundang-undangan, sistematika hukum harmonisasi hukum dan perbandingan hukum dari suatu Perundang-undangan.

Bahan hukum yangdipergunakan dalam penelitian ini terdiri dari Bahan Hukum Primer yaitu data yang berupa bahan hukum dan berasal dari aturan yang mengikat seperti peraturan Perundang-undangan, perjanjian dan konvensi internasional. Selain itu digunakan juga Bahan Hukum Sekunder yang diperoleh dari berbagai kepustakaan seperti buku dan hasil penelitian.

\section{HASIL DARI PEMBAHASAN 3.1 Pemikiran Hukum Adanya Diskresi Dalam Rangka Good Governance}

Salah satu aspek penting yang terkait dengan prinsip akuntabilitas dalam reformasi birokrasi Indonesia saat ini adalah perihal kewenangan diskresi. Sebagaimana diketahui diskresi atau yang lazim dikenal dengan bahasa Jerman sebagai Freies Ermessen merupakan suatu bentuk penyimpangan terhadap asas legalitas dalam pengertian pemerintahan yang berdasarkan peraturan-peraturan (wet matigheid van bestuur). Diskresi dapat dikatakan sebagai bentuk wewenang Badan atau Pejabat Pemerintahan yang memungkinkan untuk mengambil tindakan hukum atau tindakan faktual dalam lingkup administrasi tata kelola suatu pemerintahan. 
Diskresi diperlukan sebagai pelengkap asas legalitas yaitu asas hukum yang menyatakan bahwa setiap tindakan administrasi negara harus berdasarkan ketentuan undangundang, akan tetapi tidak mungkin bagi undang-undang untuk mengatur segala macam hal dalam praktek kehidupan sehari-hari. Oleh sebab itu diperlukan adanya kebebasan atau diskresi pada Pejabat Publik dalam melaksanakan tugas dan kewajiban yang dibebankan kepadanya ${ }^{10}$. Kelebihan dari penggunaan diskresi olehPejabatPemerintahyaitukebijakan Pemerintah yang bersifat emergency terkait hidup orang banyak dapat segera diberlakukan meskipun masi debatable secara yuridis. Kerugian yang biasanya terjadi dalam pemberlakuan kebijakan ini adalah adanya kesewenangan Pejabat Pemerintah dan aktivitas perekonomian masyarakat justru menjadi pasif dan tidak berkembang akibat sejumlah kebijakan (policy) yang tidak pro masyarakat dan terjadi krisis kepercayaan publik terhadap penguasa dan menurunnya wibawa pemerintah dimata masyarakat sebagai akibat kebijakan yang dinilai tidak simpatik dan merugikan masyarakat ${ }^{11}$.

Terdapat beberapa parameter dalam hal batasan toleransi bagi Badan atau Pejabat Pemerintahan dalam menggunakan asas diskresi yaitu adanya kebebasan administrasi

10 Ridwan, 2009, Hukum Administrasi Didaerah, Fh UUI, Jakarta, hlm. 23.

11 Subarsono, 2005, Analisis Kebijakan Publik, Pustaka Pelajar, Jakarta, hlm. 46 negara untuk bertindak atas inisiatif sendiri, untuk menyelesaikan persoalan yang mendesak yang belum ada aturannya untuk itu dan tidak boleh mengakibatkan kerugian kepada masyarakat harus dapat dipertanggungjawabkan secara hukum dan moral. Bila berbicara mengenai pertanggungjawaban maka diskresi akan terkait dengan permasalahan subyek yang memiliki kewenangan membuat diskresi ${ }^{12}$.

Penerapan diskresi dalam good governance merupakan suatu peranan pemerintah dengan mengikuti kaidah-kaidah sesuai dengan prinsipprinsipnya, terdapat beberapa hal yang perlu dilaksanakan pemerintah guna ter arahnya pembangunan yaitu pemerintah sebagai Leading Sector dengan membuat kebijakan-kebijakan, pemerintah sebagai sumber dana dalam hubungannya dengan pembiayaanpembiayaan di ruang lingkup kesehatan yang sangat kompleks, serta sebagai pelayan masyarakat dimana pemerintah meningkatkan sumber daya aparaturnya guna dapat melaksanakan pelayanan prima untuk seluruh masyarakat ${ }^{13}$.

Pemisahan antara eksekutif dengan legislatif akan dapat meningkatkan pengawasan terhadap pemerintah daerah dalam penyelenggaraan pemerintah

$12 \quad$ Ibid., hlm.87

13 Pemerintahan, http://chandrax.wordpress. com/2007/02/05/peranan-pemerintah-dalamgood-governance, diakses pada 4 November 2017. 
daerah. Badan legislatif diharapkan lebih mampu menampung dan menyuarakan aspirasi masyarakat sehingga diharapkan penyelenggaraan pemerintah daerah yang baik dapat terwujud. Oleh karena itu penyelenggaraan pemerintah daerah yang baik diselenggarakan sesuai dengan ketentuan peraturan perundangan yang berlaku, pemerintah daerah yang diselenggarakan sematamata memenuhi aspirasi rakyat atau pemerintah dengan memperhatikan aspirasi rakyat sesuai dengan ketentuan peraturan perundangan yang berlaku ${ }^{14}$.

Selanjutnya dalam penyusunan peraturan daerah yang menyangkut hajat hidup orang banyak hendaknya masyarakat sebagai stakeholders dilibatkan secara proporsional. Hal ini di samping untuk mewujudkan transparansi juga akan sangat membantu pemerintah daerah dan Dewan Perwakilan Rakyat Daerah dalam membuat peraturan daerah yang accountable dan dapat menampung aspirasi masyarakat ${ }^{15}$.

\subsection{Implikasi Penggunaan Diskresi} Dihadapkan Dengan Pidana Korupsi Terhadap Pejabat Penyelenggara Pemerintah

Secara umum istilah korupsi selama ini mengacu kepada berbagai

14 I Gde Pantja Astawa, 2009, Problema Hukum Otonomi Daerah di Indonesia, Alumni, Bandung, hlm. 87

15 Good governance, http://www.aplikasi.or.id/ modules.php $/$ name $=$ News \& file $=$ article $\&$ sid97, diakses pada 7 November 2017. tindakan gelap dan tidak sah (illicit or illegal activities) untuk mendapatkan keuntungan pribadi atau kelompok. Tetapi dalam perkembangannya lebih akhir dari beragam pengertian korupsi terdapat penekanan bahwa korupsi adalah penyalahgunaan kekuasaan atau kedudukan publik untuk keuntungan pribadi.

Upaya seorang Pejabat untuk menghindari korupsi dalam tugasnya sebagai penyelenggara negara harus bersumpah sesuai dengan agamanya dan harus mengumumkan dan bersedia diperiksa kekayaannya sebelum dan setelah menjabat., melaksanakan tugas tanpa membeda-bedakan suku, agama, ras, dan golongan. Seorang Pejabat harus melaksanakan tugas dengan penuh tanggung jawab, tidak melakukan perbuatan tercela, dan tidak mengharapkan imbalan dalam bentuk apapun yang bertentangan dengan ketentuan Peraturan PerundangUndangan yang berlaku ${ }^{16}$.

Penggelapan, kecurangan, atau penipuan dan pemerasan termasuk dalam bentuk korupsi yang biasanya hanya melibatkan individu itu sendiri, tidak melibatkan sesama pegawai atau dengan klien. Bentuk lain misalnya melebihkan budget kantor, membeli peralatan kantor yang tidak perlu atau memungut pajak untuk dimasukan ke kantong sendiri ${ }^{17}$.

\footnotetext{
16 Indriyanto, 2007, Korupsi Dan Kebijakan Aparatur Negara, Diadit Media, Jakarta, hlm.32.

17 Ibid.
} 


\section{Korupsi}

tidak efisiensinya birokrasi dan meningkatnya biaya administrasi dalam birokrasi. Jika birokrasi telah didukung oleh korupsi dengan berbagai bentuknya,maka prinsipdasarbirokrasi yang rasional, efisien, dan kualifikasi akan tidak pernah terlaksana. Kualitas layanan pasti sangat jelek dan mengecewakan publik. Keadaan ini dapat menyebabkan meluasnya keresahan sosial, ketidaksetaraan sosial, dan selanjutnya mungkin kemarahan sosial yang menyebabkan jatuhnya para birokrat ${ }^{18}$.

Kebijakan yang melahirkan korupsi muncul ketika seorang pejabat publik yang telah dipercayakan untuk membuat kebijakan terbaik bagi rakyat, ternyata menghasilkan kebijakan semu yang tidak berdampak positif bagi masyarakat bahkan merugikan keuangan negara. Hal ini lah yang mulai perlu diperhatikan dengan saksama oleh masyarakat juga pemerintah yang ingin menjalankan good governance dengan benar. Tidak efektifnya kebijakan yang dikeluarkan oleh seorang pejabat publik selama menjabat, jika dihubungkan dengan unsur-unsur tindakan korupsi memang bukan merupakan perbuatan melawan hukum. Namun bisa dipastikan bahwa hal tersebut merugikan keuangan negara bahkan perekonomian negara. Seorang pejabat publik yang dilantik

18 Hukum Korupsi, https;//nurkholis77.staff. uii.ac.id/korupsi-dan-akibatnyaanalisisperspektif-ekonomi-islam. Diakses pada 3 November 2017. dengan gaji dan fasilitas terjamin sudah seharusnya bekerja keras untuk kepentingan rakyat banyak., dan kebijakan yang dihasilkan harus bisa berdampak baik untuk masyarakat.

Agar kebijakan memberikan hasil optimal dalam mewujudkan kebaikan dan kesejahteraan umum, sumber daya publik haruslah dikelola dengan prinsip-prinsip tata kelola yang baik (good governance). Prinsip-prinsip tata kelola yang baik yaitu efisien, efektif, transparan, akuntabel, partisipatif, berdasarkan hukum, berdasarkan konsensus, dan berorientasi pada penegakan keadilan. Berdasarkan prinsip-prinsip tersebut maka anggaran dan aset-aset publik tidak boleh dikuasai untuk kepentingan pribadi, keluarga, kelompok, kolega dan golongan tertentu. Tetapi Pejabat publik yang dipilih dan pegawai negeri berhak mendapatkan imbalan atas pekerjaannya sesuai dengan peranannya di lembaga-lembaga publik dan birokrasi ${ }^{19}$.

Dalam melakukan aktivitasnya, pemerintah melakukan dua macam tindakan, tindakan biasa (feitelijke handelingen) dan tindakan hukum (rechts handelingen). Tindakan hukum pemerintahan adalah tindakan yang dilakukan oleh Badan atau Pejabat Tata Usaha Negara dalam rangka melaksanakan urusan pemerintahan. Tindakan pemerintah memiliki beberapa unsur yaitu sebagai alat perlengkapan pemerintah (bestuurs

19 Indriyanto, op.cit, hlm.185 
ornagen), perbuatan itu dilaksanakan dalam rangka menjalankan sebagai fungsi pemerintahan, dan perbuatan tersebut dimaksudkan sebagai sarana untuk menimbulkan akibat hukum di bidang hukum administrasi ${ }^{20}$.

Sumber-sumber kewenangan yang dimiliki oleh pemerintah bersumber pada atribusi, delegasi, dan mandat. Atribusi adalah pemberian kewenangan oleh pembuat Undangundang sendiri kepada suatu organ pemerintahan baik yang sudah ada maupun yang baru. Delegasi adalah penyerahan wewenang yang dipunyai oleh organ pemerintahan kepada organ yang lain. Adapun pengertian dari mandat ialah tidak terjadi suatu pemberian wewenang baru maupun pelimpahan wewenang dari Badan atau Pejabat Tata Usaha Negara yang satu dengan yang lain, tanggungjawab kewenangan atas dasar mandat masih tetap pada pemberi mandat dan tidak beralih kepada penerima mandat.

Secara spesifik fungsi Hukum Administrasi Negara dikemukakan oleh Philipus M.Hadjon yakni fungsi normatif, fungsi instrumental, dan fungsi jaminan. Fungsi normatif menyangkut penormaan kekuasaan memerintah jelas berkaitan erat dengan fungsi instrumental yang menetapkan instrumen digunakan oleh pemerintah untuk menggunakan kekuasaan memerintah dan pada akhirnya norma pemerintahan dan

20 Djenal Husein Koesoemahatmadja, 1979, Pokok-Pokok Hukum Tata Usaha Negara, Alumni: Bandung, hlm.41. instrumen pemerintahan dan instrumen pemerintahan yang digunakan harus menjamin perlindungan hukum bagi rakyat $^{21}$. Oleh karena itu dengan adanya fungsi Hukum Administrasi Negara akan tercipta pemerintahan yang bersih. Pemerintah menjalankan aktivitas sesuai dengan ketentuan yang berlaku atau berdasarkan asas legalitas, dan ketika menggunakan diskresi pemerintah memperhatikan asas-asas umum yang berlaku, sehingga dapat dipertanggungjawabkan secara moral dan hukum.

Pemberian dan penggunaan kewenangansecaratidakterkontrololeh hukum dan pengawasan masyarakat dapat menjerumuskan para penguasa birokrasi dan pejabat pemerintah kepada perbuatan yang sewenangwenang $^{22}$. Hukum administrasi negara diartikan sebagai perangkat hukum yang mengatur segala sesuatu yang berkaitan dengan administrasi negara. Sedangkan administrasi pemerintahan adalah tata laksana dalam mengambil tindakan hukum atau tindakan faktual oleh Badan atau Pejabat pemerintahan yang melaksanakan fungsi pemerintahan berdasarkan wewenang diluar kekuasaan legislatif dan yudisial yang diperoleh melalui atribusi, delegasi, dan mandat ${ }^{23}$.

21 Philipus M.Hadjon, 1993, Pengantar Hukum Administrasi Indonesia, Gajah Mada University Press, Yogyakarta, hlm.25.

22 Sjahran Basah, 1985, Eksistensi Dan Tolak Ukur Badan Peradilan Administrasi Negara, Alumni, Bandung, hlm.16.

23 Irawan Soedjito, 1983, Pengawasan Terhadap Peraturan Daerah, Bina Aksara, Jakarta, hlm.54. 
Pada tanggal 16 Agustus 1999 diterbitkan Undang-Undang Nomor 31 Tahun 1999 adalah untuk menambah ketentuan tentang pembalikan beban pembuktian. Dirumuskan dua jenis ketentuan tentang pembalikan beban pembuktian, yang pertama menyangkut pemberian dalam jumlah satu juta rupiah harus dilaporkan, jika tidak sanggup dianggap suap sampai dapat dibuktikan sebaliknya. Dalam perkembangannya Undang-Undang Nomor 31 Tahun 1999 Jo. UndangUndang Nomor 20 Tahun 2001 telah secara rinci menjelaskan mengenai definisi korupsi kedalam tiga puluh jenis tindak pidana korupsi dalam 13 Pasal, yang mana ketiga puluh jenis tindak pidana korupsi tersebut pada dasarnya dapat dikelompokkan menjadi tujuh kelompok besar, yaitu : kerugian keuangan negara, suapmenyuap, penggelapan dalam jabatan, pemerasan, perbuatan curang, benturan kepentingan dalam pengadaan, gratifikasi ${ }^{24}$.

Undang-Undang Pemberantasan Tindak Pidana Korupsi Nomor 31 Tahun 1999 Pasal 2 menyebutkan unsur yang dapat merugikan negara atau perekonomian negara. Perumusan ini dapat diartikan sebagai langsung atau tidak langsung merugikan keuangan negara atau perekonomian negara, atau patut disangka olehnya bahwa perbuatan tersebut merugikan keuangan negara atau perekonomian negara. Dalam unsur tersebut terdapat 24 KPK, 2006, Buku Saku Untuk Memahami Tindak Pidana Korupsi, Jakarta. unsur tidak langsung yang tidak dikenal dalam hukum pidana Indonesia adanya akibat dari sebab yang tidak langsung. Hal ini mengingatkan kepada Teori Von Buri yang terkenal dengan nama aequivalentie (ekivalensi) atau condition sine qua non. Menurut Von Buri semua faktor yaitu semua syarat yang turut serta menyebabkan suatu akibat dan yang tidak dapat weggedacht (dihilangkan) dari rangkaian faktor yang bersangkutan harus dianggap sebagai sebab (causa) akibat itu ${ }^{25}$.

\section{KESIMPULAN}

Ada beberapa manfaat atau aspek kelebihan dalam penggunaan diskresi oleh pejabat pemerintah yaitu Kebijakan pemerintah yang bersifat emergency terkait hajat hidup orang dapat segera diputuskan atau diberlakukan oleh pemerintah meskipun debatable secara yuridis atau bahkanterjadikekosonganhukumsama sekali. Badan atau Pejabat pemerintah tidak terjebak pada formalisme hukum dengan asumsi bahwa tidak ada kekosongan hukum bagi setiap kebijakan publik (policy) sepanjang berkaitan dengan kepentingan umum atau masyarakat luas. Sifat roda pemerintahan menjadi semakin fleksibel, sehingga sektor pelayanan publik makin hidup dan pembangunan bagi peningkatan kesejahteraan rakyat menjadi tidak statis alias tetap

25 Andi Hamzah, 2007, Pemberantasan Korupsi Melalui Hukum Pidana Nasional dan Internasional, Raja Grafindo Persada, Jakarta, hlm.195. 
dinamis seiring dengan dinamika masyarakat dan perkembangan jaman. Namun begitu di sisi lain kebebasan bertindak oleh aparatur pemerintahan yang berwenang sudah tentu juga menimbulkan kompleksitas masalah karena sifatnya yang menyimpangi asas legalitas dalam arti yuridis (unsur exception). Memang harus diakui apabila tidak digunakan secara cermat dan hati-hati maka penerapan diskresi ini rawan menjadi konflik struktural yang berkepanjangan antara penguasa dengan masyarakat. Aparatur atau pejabat pemerintah bertindak sewenang-wenang karena terjadi ambivalensi kebijakan yang tidak dapat dipertanggung jawabkan terhadap masyarakat. Sektor pelayanan publik menjadi terganggu atau malah makin buruk akibat kebijakan yang tidak populer dan nonresponsif diambil oleh pejabat atau aparatur pemerintah yang berwenang. Sektor pembangunan justru menjadi terhambat akibat sejumlah kebijakan (policy) pejabat atau aparatur pemerintah yang kontra produktif dengan keinginan rakyat sehingga membebaskan korupsi dalam hal ini, aktivitas perekonomian masyarakat justru menjadi pasif dan tidak berkembang akibat sejumlah kebijakan (policy) yang tidak pro masyarakat dan terakhir adalah terjadi krisis kepercayaan publik terhadap penguasa dan menuruni wibawa pemerintah di mata masyarakat sebagai akibat kebijakan-kebijakannya yang dinilai tidak simpatik dan merugikan masyarakat.
Diantara asas-asas umum pemerintahan yang baik dan paling mendasar adalah larangan penyalahgunaan wewenang dan larangan bertindak sewenang-wenang. Badan atau Pejabat pemerintahan yang menggunakan diskresi wajib mempertanggungjawabkan keputusannyakepadapejabatatasannya dan masyarakat yang dirugikan akibat keputusan diskresi yang telah diambil. Pertanggungjawaban kepada atasan dilaksanakan dalam bentuk tertulis dengan memberikan alasan-alasan pengambilan keputusan diskresi. Dengan demikian diskresi muncul karena adanya tujuan kehidupan bernegara yang harus dicapai, tujuan bernegara dari paham negara welfare state adalah untuk menciptakan kesejahteraan rakyat. Negara Indonesia merupakan bentuk negara kesejahteraan modern yang tercermin dalam pembukaan Undang-Undang Dasar Tahun 1945 dimana di dalam paragraf keempat tergambarkan secara tegas tujuan bernegara yang hendak dicapai. Untuk mencapai tujuan bernegara tersebut maka pemerintah berkewajiban memperhatikan dan memaksimalkan upaya keamanan sosial dalam arti seluas-luasnya dan menghilangkan korupsi dalam pemuatan hal yang sekecil-kecilnya. Maka hal tersebut mengakibatkan pemerintah harus aktif berperan mencampuri bidang kehidupan sosial ekonomi masyarakat (public service) yang mengakibatkan administrasi negara tidak boleh 
menolak untuk mengambil keputusan ataupun bertindak dengan dalih terjadi kekosongan hukum (rechtsvacuum). Dengan adanya keleluasaan bergerak yang diberikan kepada administrasi negara yaitu pemerintah yang merupakan suatu kebebasan bertindak (Pouvoir Discretionnaire/Freies Ermessen).

\section{DAFTAR PUSTAKA}

\section{Buku}

Andi Hamzah, 2007, Pemberantasan Korupsi Melalui Hukum Pidana Nasional dan Internasional, Raja Grafindo Persada, Jakarta.

Djenal Husein Koesoemahatmadja, 1979, Pokok-Pokok Hukum Tata Usaha Negara, Alumni, Bandung.

I Gde Pantja Astawa, 2009, Problema Hukum Otonomi Daerah di Indonesia, Alumni.

Indriyanto, 2007, Korupsi Dan

Kebijakan Aparatur Negara, Diadit Media.

Irawan Soedjito, 1983, Pengawasan

Terhadap Peraturan Daerah, Bina Aksara, Jakarta.

KPK, 2006, Buku Saku Untuk Memahami Tindak Pidana Korupsi, Jakarta.

Philipus M.Hadjon, 1993, Pengantar Hukum Administrasi Indonesia, Gajah Mada University Press.

Ridwan, 2009, Hukum Administrasi Di daerah, FH UUI.

Sjahran Basah, 1985, Eksistensi Dan Tolak Ukur Badan Peradilan Administrasi Negara, Alumni
Bandung.

Subarsono, 2005, Analisis Kebijakan Publik, PUSTAKA PELAJAR.

\section{Jurnal}

Ni Luh Gede Astariyani, Kewenangan Pemerintah Dalam Pembentukan Peraturan Kebijakan,. Jurnal Magister Hukum Udayana (Udayana Master Law Journal), vol.4 no.4 tahun 2015. https// ojs.unud.ac.id/index.php/jmhu/ article/view/18746/12225, diakses pada 23 November 2017.

I Gustu Ayu Wviani Yuliantari, Legal Standing Komisi Pemberantasan Tindak Pidana Korupsi Dalam Sengketa Kewenangan Lembaga Negara Di Mahkamah Konstitusi, Jurnal Magister Hukum Udayana (Udayana Master Law Journal), vol.4 no.2 tahun 2015, https// ojs.unud.ac.id/index.php/jmhu/ article/view/17525/11475, diakses pada 23 November 2017.

Made Suteja, Pengawasan Terhadap Penyalahgunaan Wewenang Polri Mengadakan Tindakan Lain Menurut Hukum Yang Bertanggungjawab (Diskresi), Jurnal Magister Hukum Udayana (Udayana Master Law journal), vol.2 no.2 tahun 2015,https// ojs.unud.ac.id/index.php/jmhu/ article/view/7283/5526, diakses pada 23 November 2017.

Teguh Kurniawan, Desertasi, Isu Diskresi Dalam Kasus Korupsi 
Kepala Daerah Yang Ditangani Oleh Komisi Pemeberantasan Korupsi Pada Periode 2004-2010 dab Telah Memiliki Kekuatan Hukum Tetap, Universitas Indonesia, Jakarta, available at: https://www.researchgate. net/profile/Teguh_Kurniawan/ publication/317845377. Isu_Direksi_dalam_Kasus_ Korupsi_Kepala_Daerah_ yang_Ditangani_oleh_Komisi_ Pemberantasan_Korupsi pada_Periode_2004_2010_ dan_ Telah_Memiliki Kekuatan_ Hukum_Tetap_ or_in_English_Issues_on_ Discretion_in_Cor/links/ 594e31e945851543382e9bfd/ Isu-Diskresi-dalam-KasusKorupsi-Kepala-Daerahyang-Ditangani-oleh-KomisiPemberantasan-

Korupsi-pada-Periode-20042010-dan-Telah-

Memiliki-Kekuatan-HukumTetap-or-in-English-Issues-onDiscretion-in-Cor.pdf. diakses pada 1 November 2017.

\section{Internet}

Anonim, http://bali.bisnis.com/ $\mathrm{read} / 20140324 / 9 / 43889 / \mathrm{ma}-$ vonmantan-bupati-jembranawinasa-, http://m.tempo.co/ $\mathrm{read} / 2012 / 11 / 08 / 063440456 /$ Mantan-Bupati-Sragen-SegeraDijebloskan-ke-Penjara diakses pada 26 November 2017.

Freies Ermessen, http://malutspot.com/ berita/index.php?option $=$ com conten\&task=view \&id=163 \&Itemid $=38$, diakses pada 1 November 2017.

Diskresi, http://www.hukumonline. $\mathrm{com} / \mathrm{k} 1 \mathrm{in} \mathrm{i} \mathrm{k/d} \mathrm{e} \mathrm{t} \mathrm{a} \mathrm{i} 1 /$ 1t54b538f5f35f5/arti--tujuan-lingkup-dan-contoh-diskresi, diakses pada 23 November 2017.

Pemerintahan, http://chandrax. wordpress.com/2007/02/05/ peranan-pemerintah-dalamgood-governance, diakses pada 4 November 2017.

Good governance, http://www. aplikasi.or.id/modules.php/nam $\mathrm{e}=$ News \& file $=$ article $\&$ sid $=97$, diakses pada 7 November 2017.

Hukum Korupsi, https;//nurkholis77. staff.uii.ac.id/korupsi-danakibatnyaanalisis-perspektifekonomi-islam. Diakses pada 3 November 2017.

\section{Peraturan Perundang-Undangan}

Undang-Undang Nomor 31 Tahun 1999 Tentang Pemberantasan Tindak Pidana Korupsi.

Undang-Undang Nomor 30 Tahun 2014 Tentang Administrasi Pemerintahan

Undang-Undang Nomor20 Tahun2001 Tentang Pemberantasan Tindak Pidana Korupsi (PERUBAHAN A $T$ A $S$ U N D A N G UNDANG NOMOR 31 TAHUN 1999 TENTANG PEMBERANTASAN TINDAK PIDANA KORUPSI). 